\title{
New development of building energy efficiency---Precast concrete structure (PCS)
}

\author{
$\mathrm{Li}$-Xin $\mathrm{Li}^{1, \mathrm{a}}$, Pei-shi $\mathrm{Li}^{2, \mathrm{~b}^{*}}$ \\ ${ }^{1,2}$ Shenyang hunan-east road NO.9 Shenyang Jianzhu University, Liaoning province, China. \\ a272186748@qq.com, lipeishi0208@163.com
}

Keywords: Precast concrete structure, Energy saving, Production, Installation

Abstract: Sustainable development puts forward new requirements on building technology, improve the level of housing industrialization and modernization is the important way to realize the green building, green construction. This article from the assembled structure of production assembly to the assembled structure of the site construction installation are introduced two important links fabricated structure to reduce environmental pollution, have the effect of reducing construction waste.

\section{Introduction}

Precast concrete structure refers to the components in the factory or construction site prefabrication, using mechanical lifting and certain connection, connect scattered prefabricated as a whole and form the structure of "the advantage is of good quality, high production efficiency, workers labor intensity low, protect the environment, is advantageous to the social sustainable development" adopts modular structure, can effectively save resources and energy, improve the materials in the real construction energy conservation and structural performance in terms of efficiency, reduce the site construction conditions such as the site requirements, reduce construction waste and adverse impact on the environment and improve the building function and the structure performance, to achieve "four section, the environmental protection" green development requirements, realize the construction process of low energy consumption, low emissions, promote the overall development of construction industry in our country, realize the goal of energy conservation and emissions reduction in the book "prefabricated reinforced concrete frame structure is fabricated structure in the overall performance, good seismic performance, and the more research and application of structure system.

From Japan, the United States, Hong Kong, China, or some European countries or regional housing industrialization development experience, through the construction system of standardization, technology integration to build housing, can not only satisfy people's demand for housing, and can improve the comprehensive performance of housing. More importantly, it conforms to the concept of sustainable development of architecture, is the important way to realize the green building, green construction. Have data show that residential precast rate of $37 \%$, can save water by $36 \%$, save electricity by $31 \%$, and $83 \%$ less garbage, $60 \%$ less waste of materials, energy saving more than $50 \%$. Improve the level of industrialization to promote domestic housing industrialization and modernization has become the only way for the development of the housing. 


\begin{tabular}{|c|c|c|c|}
\hline \multirow[t]{2}{*}{ Items } & \multicolumn{3}{|c|}{ Precast Concrete Structure } \\
\hline & Frame structure & Shear wall structure & frame-wall structure \\
\hline Structure system & $\begin{array}{l}\text { Seismic framework } \\
\text { Frame structure }\end{array}$ & $\begin{array}{c}\text { L-Board system } \\
\text { Half-PCS } \\
\text { PCS } \\
\text { Precast wall system }\end{array}$ & $\begin{array}{c}\text { HPC (Japan ) } \\
\text { Parking building } \\
\text { system（America） }\end{array}$ \\
\hline Precast content & $\begin{array}{l}\text { Composite beams } \\
\text { Composite plate } \\
\text { Precast column } \\
\text { Precast stairs } \\
\text { Precast balcony }\end{array}$ & $\begin{array}{l}\text { Composite plate } \\
\text { Precast cladding } \\
\text { Precast stairs } \\
\text { Precast balcony }\end{array}$ & $\begin{array}{l}\text { Composite beams } \\
\text { Composite plate } \\
\text { Precast column } \\
\text { Precast stairs } \\
\text { Precast balcony }\end{array}$ \\
\hline Assembly features & $\begin{array}{l}\text { After pouring concrete } \\
\text { connection beam, slab, } \\
\text { column to form a } \\
\text { whole }\end{array}$ & $\begin{array}{l}\text { Through the } \\
\text { cast-in-place concrete } \\
\text { wall and composite } \\
\text { floor will be } \\
\text { prefabricated cladding, } \\
\text { stairs, balcony, etc for } \\
\text { whole connection. }\end{array}$ & $\begin{array}{c}\text { Through the } \\
\text { cast-in-place shear wall } \\
\text { and superimposed floor } \\
\text { connection of } \\
\text { prefabricated. Column } \\
\text { or floor slab } \\
\text { cast-in-place may be } \\
\text { adopted }\end{array}$ \\
\hline Scope of application & $\begin{array}{l}\text { anti-seismic grade } 1 \\
\text { fortification intensity:8 } \\
\text { structural heigh: } 45 \mathrm{~m}\end{array}$ & $\begin{array}{l}\text { anti-seismic grade } 1 \\
\text { fortification intensity: } 8 \\
\text { structural heigh: } 100 \mathrm{~m}\end{array}$ & $\begin{array}{l}\text { anti-seismic grade } 1 \\
\text { fortification intensity: } 8 \\
\text { structural heigh: } 100 \mathrm{~m}\end{array}$ \\
\hline
\end{tabular}

\section{The development of PCS}

\section{The development in China}

$\mathrm{S}$ and eighty $\mathrm{s}$ of the 20th century in China using the prefabricated concrete structure housing system mainly prefabricated plate, and precast round hole, large roof board, trough plate, etc. The application of prefabricated. Due to the production, installation of components and structure model and the way of component connection problems, these structures in seismic safety, physical properties and architectural function there are some problems in different degrees, in the $1990 \mathrm{~s}$ has gradually be eliminated. At present, the development of prefabricated concrete structure should be completely meet the current national standards (including seismic code) requirement, even than the cast-in-place structure has better safety, applicability and durability of the structure of the system. Such as: prefabricated frame structures, prefabricated, prefabricated frame - shear wall structure cast-in-place shear wall structure system (core tube).

The development abroad

In North America, mainly The United States and Canada. Because of precast, prestressed concrete association (PCI) long-term research and promotion of prefabricated buildings, precast concrete related standards is also very perfect, so the prefabricated concrete application is widespread. North American prefabricated buildings including prefabricated wall and the structure of prefabricated two big series, the common characteristic of prefabricated is large in combination with prestressed structure can optimize the structure reinforcement and connection, reduce the workload of production and installation, shorten the construction period, fully embody the industrialization, standardization, and technical economic characteristics. Draw lessons from the successful experience of Europe and the United States, Japan and South Korea on the basis of exploring the standardization of 
prefabricated building design and construction, combined with their own requirements, the prefabricated structure integrity and seismic isolation design has made breakthrough progress. Precast concrete construction system design at the same time, Japan \% of production and construction standards and regulations is also very perfect currently used prefabricated specification has the precast concrete engineering and concrete walls.

\section{The production of PCS}

Main technological process: prefabricated production mold cleaning, apply release agent, mold assembly, insulation board placed, steel skeleton placed, hardware fixed, concealed engineering acceptance, concrete is poured concrete shape, release the lifting, roll over identity, transhipment on deposit, spray paint factory to factory inspection, loading.

\section{Mould fabrication and assembly}

Components according to the different shape, mold into bottom die, die, side die inside and outside, mold and so on four parts, are removable, movable bolt connection mode, has enough stiffness and accuracy, template assembly location accurate, easy to operate. Mold manufacture high accuracy requirement, geometry size deviation must be controlled in the range of allowable design requirements, the length, width and height to allow deviation to $2 \mathrm{~mm}$, diagonal allowable deviation 3 $\mathrm{mm}$, lateral die, die flatness tolerance $1 \mathrm{~mm}$ steel mould to the factory after, according to process plan placed to designated location, bottom die after installed, elevation is measured with high precision level, control the elevation difference within a $1 \mathrm{~mm}$, adjusted fixed. Mold assembly should according to the outside, behind the bottom first, then hang after the first mold assembly sequence. Mold in contact with the concrete surface after cleaning must apply release agent, gaps between the template need to use double-sided adhesive stickers, prevent leak slurry.

\section{Insulation board production.}

HR insulation decorative materials production is the main process of XPS plate composite with calcium silicon plate. Due to the calcium silicon plate the original flatness of plate, the surface wait for a reason, needs to undertake roller coated UV primer. Need to have punching board, install the anchoring a disk. To ensure HR insulation decorative sheet and concrete layer mechanical connection, in this system, using special anchor pieces, a head of connection insulation board, the other end anchored in the concrete to increase the concrete and the compressive force of extruded board, in the back of XPS plate must be slotted surface treatment, groove width $5 \mathrm{~mm}, 5 \mathrm{~mm}$ deep.

\section{The installation of PCS}

When processing prefabricated in the factory, according to the component quality select different diameter HPB235 reinforced as hook..

When binding floor reinforced, according to the construction drawings and put down axis line of prefabricated panel brace up quick-release connector, built-in parts and steel welding of the floor slab, in order to guarantee its robustness, increase the corresponding reinforcement. Shall, after the completion of welding in the subsequent construction and concrete pouring process of the floor slab, construction personnel should pay attention to protect, prevent collision shall cause displacement, in order to dock with the brace.

\section{Conclusions}

In the concept of green, low carbon economy driven, many construction enterprises to carry out the housing construction of prefabricated concrete structure actively explore and research and development, gradually formed a structure with the characteristic of enterprise to build the new 
technology. Precast concrete frame structures due to its in line with the 12th five-year plan put forward in building a resource-conserving, environment-friendly society's request, can effectively save resources and energy, improve the materials in the real construction energy conservation and efficiency, structure performance to reduce construction waste and adverse impact on the environment and improve the building function and the structure performance, realize the environmental protection "'" four green development and low energy consumption. Construction of the low emission process, promote the overall development of China's construction industry, achieving energy conservation and emissions reduction targets, thus has broad application prospects.

\section{References}

[1] Zi-kang Chen, Yun Zhou, Ji-chao Zhang, Chong-xiao Wu. The research and application of precast concrete frame structure $[\mathrm{J}]$. Earthquake resistant Engineering and Retrofitting 2012,34(4):1-11.

[2] Lv Xi-lin, Fan Li,Zhao Bin. Pseudodynamic Test on a Reduced Scale Jointed Precast

Concrete Frame Structure [J]. Journal of Building Structures,2008,29(4):58-65

[3] Wang Xing-yuan. Chaos of Complex Nonlinear System [M]. Beijing:Electronic Industry Press ,2003

[4] L. Jaillon, C. Poon, The evolution of prefabricated residential building systems in Hong Kong: A review of the public and the private sector [J], Automation in Construction, vol.18, pp. 239-248, 2009.

[5] Candace Say, Antony Wood, Sustainable rating systems around the world [J], CTBUH Journal, 2008 Issue II, 19-29.

[6] Yee, Alfred A. Structural and Economic Benefits of Precast Prestressed Concrete Construction[J], PCI Journal, 2001, Vol.46 (4):3442. 